\title{
PAROTID GLAND TUMOURS: A CLINICOPATHOLOGICAL STUDY
}

\author{
Ramesh P. $K^{1}$, Nivee N², S. Muneeruddin Ahmed ${ }^{3}$
}

${ }^{1}$ Assistant Professor, Department of Surgery, KMCT Medical College, Manassery, Kozhikode, Kerala.

${ }^{2}$ Assistant Professor, Department of ENT, KMCT Medical College, Manassery, Kozhikode, Kerala.

3 Professor, Department of ENT, Kannur Medical College, Kannur, Kerala.

ABSTRACT
BACKGROUND
Salivary gland tumours are interesting and challenging due to their relative infrequency of incidence, Histopathological (HPE)
and behavioural diversity and the regional anatomic relationship with important structures. Salivary gland tumours comprise about
$3-4 \%$ of all head and neck neoplasms. $70 \%$ of these tumours arise in parotid gland, $22 \%$ in sub-Mandibular gland and $8 \%$ in the rest.
Of these tumours $80 \%$ of parotid, $50 \%$ of sub-Mandibular, $50 \%$ of sublingual and $25 \%$ of minor salivary glands are benign. Parotid
gland is the most common site of salivary gland tumours. Most common parotid tumour is pleomorphic adenoma followed by
Warthin's tumour. Most common malignant tumour of parotid gland is muco-epidermoid carcinoma. FNAC of salivary gland swelling
is commonly accepted, sensitive and specific technique in the diagnosis of both neoplastic and non-neoplastic lesions of salivary
gland. The traditional open biopsy is no longer justified because of risk of tumour spillage and damage to the facial nerve. Treatment
of parotid tumours is either by surgery (Superficial/Total parotidectomy) alone or surgery followed by radiotherapy in certain cases.
Tumours should be excised, not enucleated.

\section{AIMS OF THE STUDY}

To study the demographic profile of patients with parotid gland tumours to study the clinico-pathological features of parotid gland tumours. To evaluate the role of FNAC in the pathological diagnosis of parotid gland tumours and to correlate the FNAC reports with histopathology. To study the various surgical procedures adopted for parotid gland tumours and the incidence of immediate complications after surgery.

\section{MATERIALS AND METHODS}

Between November 2007 and November 2009 at the Department of surgery of the Government Medical College, Calicut, Kerala 57 patients with parotid neoplasm were clinically evaluated and among them 32 were females and 25 were males. Nearly $50 \%$ of the patients belonged to $2^{\text {nd }}$ and $3^{\text {rd }}$ decades followed by $5^{\text {thand }} 6^{\text {th }}$ decades. Preliminary FNAC showed 32 (56.16\%) out of 57 as pleomorphic adenoma, followed by Warthin's tumour in 17.54\% and Muco-epidermoid carcinoma in 10.53\%. The Benign epithelial tumour was observed in $8.77 \%$, monomorphic adenoma in 3.51\% and adenoid cystic carcinoma in $3.51 \%$ of the patients.

\section{RESULTS}

All the patients were subjected to excision biopsy and Histo-pathological study. The Sensitivity of FNAC for benign tumours and malignant tumours was $100 \%$ and $80 \%$ respectively; Whereas the specificity for benign tumour and malignant tumours was $80 \%$ and $100 \%$ respectively. The Recurrence rate and post-operative facial weakness were low.

\section{CONCLUSIONS}

Sensitivity of FNAC for benign tumour was $100 \%$ and for malignant tumour was $80 \%$. Specificity of FNAC for benign tumour was $80 \%$ and for malignant tumour was $100 \%$. There were no complications attributed to FNAC.

\section{KEYWORDS}

Tumours, Parotid, Benign, Muco-Epidermoid, Acinic Cell Tumours.

HOW TO CITE THIS ARTICLE: Ramesh PK, Nivee N, Ahmed SM. Parotid gland tumours: a clinicopathological study. J. Evolution Med. Dent. Sci. 2016;5(37):2183-2188, DOI: 10.14260/jemds/2016/509

\section{INTRODUCTION}

Parotid gland is the most common site of salivary gland tumours. Most of these arise in the superficial lobe.(1) Parotid tumours present as slow growing, painless swelling either below the ear or in the upper aspect of neck.

Financial or Other, Competing Interest: None.

Submission 21-03-2016, Peer Review 15-04-2016,

Acceptance 22-04-2016, Published 06-05-2016.

Corresponding Author:

Dr. S. Muneeruddin Ahmed,

44/118, Prakash Nagar,

Kurnool-518 004,

Andhra Pradesh.

E-mail:ahmedmunirent@gmail.com

DOI: $10.14260 /$ jemds $/ 2016 / 509$
Rarely these tumours may arise from deep lobe which present as para-pharyngeal masses.(2) The utilization of parotidectomy for the treatment of neoplasms has been attributed to Betrandi.(3) In the initial efforts to treat tumours of the gland, surgeons were concerned primarily about haemorrhage; patients were inevitably left with major disfiguration if they were fortunate enough to survive a parotid resection. By the mid-19th century, focus had shifted to facial nerve anatomy and techniques that would provide access for resection with facial/cranial nerve VII (CN VII) preservation. From a historical perspective, the first operation to use ether inhalation anaesthesia was a parotid tumour resection performed by Dr. John C. Warren in Boston in 1846.(3) 
The first total parotidectomy with facial nerve preservation is said to have been accomplished by Codreanu, a Romanian, in 1892.(3) During the early years of the 20th century, many authors verified that removal of parotid gland tumours was possible with facial nerve preservation.(4) Blair, Sistrunk, and others attempted to systematize the surgical approach to the facial nerve to ensure anatomic preservation when feasible, while assuring complete resection of the tumour. The first attempts at facial nerve grafting date. From the early 1950s a major series of FNAC of salivary tumours by Lineberg and Akerman in 1972 established the role of FNAC in salivary gland disease.(5)

The course of the facial nerve through the parenchyma of the gland is highly predictable anatomically; however, parotid tumours pose a special challenge to surgeons because of the diversity of histological subtypes and their remarkable variation in clinical behaviour.(6) Small benign tumours are quite indistinguishable from their malignant counterparts. Even when benignity of the neoplasm can be established with reasonable certainty, most patients are motivated to have surgical resection due to progressive disfiguration of an enlarging benign tumour.(7) The present study was conducted to analyze the morphological, clinical features and the role of FNAC and HPE in the management of parotid glad tumours in this part of Kerala.

\section{MATERIALS AND METHODS}

The present study was conducted between November 2007 and November 2009 in the Department of surgery of the Government Medical College, Calicut, Kerala. Prior approval from the ethical committee of the institute was obtained before commencing the present study. This is a study of descriptive observations was conducted on patients presenting with swelling of the salivary glands. All the patients were subjected to haematological tests and FNAC of the tumour mass. Patients were subjected to appropriate surgical procedure depending upon the tumour mass.

Patients with parotid gland tumours were first evaluated in surgery OPD with history, clinical examination. FNAC advised for every patient and results were reviewed in the next OPD. All pre op investigations and cardiac and chest evaluation and pre anaesthetic check-up were completed before taking patient for surgery. After parotidectomy patients were shifted to post op wards. Those patients who required close monitoring were shifted to surgery ICU. Each post op patients vital, condition of wound, haemorrhage, presence of facial nerve palsy, general condition were evaluated. Sutures were removed on $5^{\text {th }}$ post op day and discharged on next day.

If any post op complications happened like flap necrosis, wound infection patient was keep in the ward till he/she improves. Patients were advised to review after 2 weeks. The follow up of these patients is done by asking them to report for regular check-up. Study design includes the study of demographic \& clinico-pathological features of parotid gland tumours and a comparison between preoperative FNAC with final histopathological diagnosis. Cytology slides are stained with Giemsa and Papanicolaou stain and biopsy slides with Haematoxylin and Eosin (H\&E) stain. The confirmation of diagnosis is done by histopathological examination of excised specimen. Galen and Gumbino method is used to calculate sensitivity and specificity of FNAC.

\section{Inclusion Criteria}

All patients aged above 13 years of both sexes attending with complaints of swelling o the salivary glands were included Patients with previous history of surgery were included. Patients with recurrence were included.

\section{Exclusion Criteria}

Patients below 13 years of age. Patients with inflammatory parotid swelling and parotid abscesses were excluded. Patients with post traumatic parotid swellings were also excluded.

\section{OBSERVATION AND ANALYSIS}

The present Study was conducted in Govt. Medical College, Kozhikode, Kerala between November 2007 and November 2009, during which 57 patients with parotid neoplasm were studied. Out of 57 patients 32 were females and 25 were males. $56.14 \%$ females and $43.86 \%$ males. Male to female ratio was 1:1.28 (Table 1).

\begin{tabular}{|c|c|c|}
\hline Sex & No & \% \\
\hline Male & 25 & 43.86 \\
\hline Female & 32 & 56.14 \\
\hline \multicolumn{2}{|c|}{ Table 1: The Sex Distribution of 57 Patients } \\
\hline
\end{tabular}

The study showed Parotid Tumours in the age groups of 18 - 70 years. The incidence was found to be highest between $2^{\text {nd }}$ and $3^{\text {rd }}$ decades $(50.87 \%)$ of life followed by 41 to 50 years (17.54\%) and 51 - 60 years (14.04\%) groups (Table 2).

\begin{tabular}{|c|c|c|c|c|}
\hline Age Group & Male & Female & Total & \% \\
\hline $0-20$ & 1 & 1 & 2 & 3.51 \\
\hline $21-30$ & 5 & 11 & 16 & 28.07 \\
\hline $31-40$ & 5 & 8 & 13 & 22.80 \\
\hline $41-50$ & 5 & 5 & 10 & 17.54 \\
\hline $51-60$ & 4 & 4 & 8 & 14.04 \\
\hline $61-70$ & 5 & 3 & 8 & 14.04 \\
\hline \multicolumn{6}{|c|}{ Table 2: Showing the Age Distribution (n=57) } \\
\hline
\end{tabular}

The size of the tumour varied in the present study from 1 $\mathrm{Cm}$ to $7 \mathrm{Cms}$. $70.18 \%$ of patients presented with tumour size ranging from $2-4 \mathrm{~cm}$. There were no patients with tumour size more than $7 \mathrm{Cms}$ (Table 3).

\begin{tabular}{|c|c|}
\hline Tumour Size & No. of Patients \\
\hline $1 \mathrm{~cm}$ & 2 \\
\hline $2 \mathrm{~cm}$ & 10 \\
\hline $3 \mathrm{~cm}$ & 20 \\
\hline $4 \mathrm{~cm}$ & 10 \\
\hline $5 \mathrm{~cm}$ & 7 \\
\hline $6 \mathrm{~cm}$ & 1 \\
\hline $7 \mathrm{~cm}$ & 1 \\
\hline \multicolumn{2}{|c|}{ Table 3: Showing the Incidence of Size } \\
of the Tumour (n=57)
\end{tabular}

Among the 57 patients $47.37 \%$ of the patients presented with parotid swelling of duration $6 \mathrm{~m}$ to $1 \mathrm{yr}$. IN $29.82 \%$ of the patients the swellings were present between 2 to 4 years. The maximum duration of the swelling presented in the present study was 8 years (Table 4). There were 2 patients presenting with recurrent parotid swelling after parotidectomy. One of them case was done in this institute and other from outside. Both were pleomorphic adenoma cases (Table 4). 


\begin{tabular}{|c|c|}
\hline Duration & No. of Patients \\
\hline $2-5 \mathrm{~m}$ & 5 \\
\hline $6-11 \mathrm{~m}$ & 14 \\
\hline 1 year & 13 \\
\hline 2 yrs. & 8 \\
\hline 3 yrs. & 6 \\
\hline 4 yrs. & 3 \\
\hline 5 yrs. & 5 \\
\hline 6 yrs. & 1 \\
\hline 7 yrs. & 1 \\
\hline 8 yrs. & 1 \\
\hline Table 4: Showing the duration of the Swellings (n=57) \\
\hline
\end{tabular}

Three patients (5.26\%) had preoperative facial nerve palsy; two out of them were with permanent and one with temporary facial nerve palsy. The two patients with permanent facial palsy were having muco-epidermoid carcinoma. 11 (19.29\%) Patients showed features of malignancy. The symptoms of presentation of these patients were shown in (Table 5).

\begin{tabular}{|c|c|}
\hline Clinical Features & No. of Patients \\
\hline Pain & 6 \\
\hline Rapid growth & 1 \\
\hline Hard consistency & 6 \\
\hline Fixity & 4 \\
\hline Cervical lymph nodes & 0 \\
\hline Trismus & 1 \\
\hline Facial nerve palsy & 3 \\
\hline Metastasis & 0 \\
\hline \multicolumn{2}{|c|}{$\begin{array}{c}\text { Table 5: Showing the Clinical Features } \\
\text { of the Swellings }(n=57)\end{array}$} \\
\hline
\end{tabular}

In the present study Imaging modalities used were CT and MRI. 8 patients took CT scan and 1 patient took MRI. 9 patients had deep lobe involvement and 2 patients had facial nerve involvement on CT/MRI (Table 6).

\begin{tabular}{|c|c|}
\hline CT/MRI Findings & $\begin{array}{c}\text { No. of } \\
\text { Patients }\end{array}$ \\
\hline Deep lobe involvement & 9 \\
\hline Facial nerve involvement & 2 \\
\hline Cervical lymph nodes & 0 \\
\hline Table 6: Showing the Radiological Signs (n=57). \\
\hline
\end{tabular}

Among the FNAC reports pre operatively 32 (56.16\%) out of 57 were showing pleomorphic adenoma, followed by Warthin's tumour in $17.54 \%$ and Muco-epidermoid carcinoma in $10.53 \%$. The Benign epithelial tumour was observed in $8.77 \%$, monomorphic adenoma in $3.51 \%$ and adenoid cystic carcinoma in $3.51 \%$ of the patients (Table 7 ).

\begin{tabular}{|c|c|c|c|c|}
\hline FNAC & Male & Female & Total & \% \\
\hline Pleomorphic adenoma & 12 & 20 & 32 & 56.16 \\
\hline Warthin's tumour & 9 & 1 & 10 & 17.54 \\
\hline $\begin{array}{c}\text { Mucoepidermoid } \\
\text { carcinoma }\end{array}$ & 3 & 3 & 6 & 10.53 \\
\hline $\begin{array}{c}\text { Benign epithelial } \\
\text { tumour }\end{array}$ & 1 & 4 & 5 & 8.77 \\
\hline $\begin{array}{c}\text { Monomorphic } \\
\text { adenoma }\end{array}$ & 0 & 2 & 2 & 3.51 \\
\hline $\begin{array}{c}\text { Adenoid cystic } \\
\text { carcinoma }\end{array}$ & 0 & 2 & 2 & 3.51 \\
\hline Table 7: Showing the FNAC Reports of Swellings (n=57) \\
\hline
\end{tabular}

Among the 57 patients Superficial parotidectomy was done in 59.6\%, Excision of deep lobe in 5.3\%, and Total conservative Parotidectomy in $15.8 \%$ of the patients. Total radical parotidectomy was done in $5.3 \%$ and Excision of the tumour masses in $10.5 \%$ of the patients (Table8).

\begin{tabular}{|c|c|c|}
\hline Type of Parotidectomy & $\begin{array}{l}\text { No. of } \\
\text { Patients }\end{array}$ & $\%$ \\
\hline Superficial parotidectomy & 34 & 59.6 \\
\hline $\begin{array}{l}\text { Superficial parotidectomy with } \\
\text { excision of deep lobe tumour }\end{array}$ & 3 & 5.3 \\
\hline Total conservative parotidectomy & 9 & 15.8 \\
\hline Total radical parotidectomy & 3 & 5.3 \\
\hline Excision & 6 & 10.5 \\
\hline Enucleations & 2 & 3.5 \\
\hline \multicolumn{3}{|c|}{$\begin{array}{c}\text { Table 8: Showing the Various Surgical } \\
\text { Modalities Done }(n=57)\end{array}$} \\
\hline
\end{tabular}

Out of 57 patients studied, 3 patients were presented with preoperative facial nerve palsy. Two with permanent and one with temporary facial nerve palsy. In remaining 54 patients, 13 had immediate post-operative temporary facial nerve palsy. No one had permanent post op facial nerve palsy. $24.07 \%$ patients had immediate postoperative temporary facial weakness as new complication. 2 patients had minimal flap necrosis and wound infection. They were treated with antibiotics and excision of necrotic area (Table 9).

\begin{tabular}{|c|c|c|}
\hline & $\begin{array}{c}\text { Pre op FN } \\
\text { Palsy } \\
\text { (3 Cases) }\end{array}$ & $\begin{array}{c}\text { Immediate Post op FN } \\
\text { Palsy (13 Cases) }\end{array}$ \\
\hline $\begin{array}{c}\text { Permanent FN } \\
\text { palsy }\end{array}$ & 2 & 0 \\
\hline $\begin{array}{c}\text { Temporary FN } \\
\text { palsy }\end{array}$ & 1 & 13 \\
\hline \multicolumn{2}{|c|}{ Table 9: Showing the Facial Palsy Incidence (n=57) } \\
\hline
\end{tabular}

The incidence of pleomorphic adenoma in males it was $13 / 57(22.80 \%)$ and in females it was $22 / 57$ (38.59\%). In case of Warthin's tumour the incidence in males it was $8 / 9$ (88.88\%), (Table 10).

\begin{tabular}{|c|c|c|c|c|c|}
\hline Tumour (HPR) & Total & Male & Female & Ratio & Age \\
\hline $\begin{array}{l}\text { Pleomorphic } \\
\text { adenoma }\end{array}$ & 35 & 13 & 22 & $1: 1.7$ & $\begin{array}{l}18- \\
70\end{array}$ \\
\hline $\begin{array}{l}\text { Warthin's } \\
\text { tumour }\end{array}$ & 9 & 8 & 1 & $8: 1$ & $\begin{array}{l}40- \\
69\end{array}$ \\
\hline $\begin{array}{l}\text { Mucoepidermoid } \\
\text { carcinoma }\end{array}$ & 6 & 3 & 3 & 1 & $\begin{array}{c}29- \\
66\end{array}$ \\
\hline $\begin{array}{l}\text { Basal cell } \\
\text { adenoma }\end{array}$ & 2 & 0 & 2 & 0 & $\begin{array}{l}26- \\
35\end{array}$ \\
\hline $\begin{array}{l}\text { Adenoid cystic } \\
\text { carcinoma }\end{array}$ & 2 & 0 & 2 & 0 & $\begin{array}{l}32- \\
35\end{array}$ \\
\hline Myoepithelioma & 1 & 0 & 1 & 0 & 30 \\
\hline Adenocarcinoma & 1 & 0 & 1 & 0 & 50 \\
\hline $\begin{array}{l}\text { Acinic cell } \\
\text { carcinoma }\end{array}$ & 1 & 1 & 0 & 0 & 30 \\
\hline Total & 57 & 25 & 32 & & \\
\hline \multicolumn{6}{|c|}{$\begin{array}{c}\text { Table 10: Showing the Incidence Various Tumours } \\
\text { and their Sex Incidence }(n=57)\end{array}$} \\
\hline
\end{tabular}

The FNAC reports and the Histo-pathological reports were compared in the present study; it showed that there was 
$100 \%$ correlation in case of Muco-epidermoid carcinoma, adenoid cystic carcinoma.

Among the 32 FNAC reports as pleomorphic adenoma 2 turned out to be basal cell adenomas and in 1 the histopathological report was adenocarcinoma (Table 11).

\begin{tabular}{|l|l|}
\hline \multicolumn{1}{|c|}{ FNAC } & \multicolumn{1}{c|}{ HPR } \\
\hline $\begin{array}{l}\text { Mucoepidermoid } \\
\text { carcinoma (6) }\end{array}$ & $\begin{array}{l}\text { Mucoepidermoid } \\
\text { carcinoma (6) }\end{array}$ \\
\hline $\begin{array}{l}\text { Adenoid cystic } \\
\text { carcinoma (2) }\end{array}$ & $\begin{array}{l}\text { Adenoid cystic carcinoma } \\
(2)\end{array}$ \\
\hline \multirow{2}{*}{$\begin{array}{l}\text { Pleomorphic } \\
\text { adenoma (32) }\end{array}$} & Pleomorphic adenoma (29) \\
\cline { 2 - 2 } & Basal cell adenoma (2) \\
\cline { 2 - 2 } Warthin's tumour (10) & Adenocarcinoma (1) \\
\hline Warthin's tumour (9) & Acinic cell carcinoma (1) \\
\hline $\begin{array}{l}\text { Benign epithelial } \\
\text { tumour (5) }\end{array}$ & Pleomorphic adenoma (4) \\
\cline { 2 - 2 } $\begin{array}{l}\text { Monomorphic } \\
\text { adenoma (2) }\end{array}$ & Myoepithelioma (1) \\
\hline \multicolumn{2}{|c|}{$\begin{array}{c}\text { Table 11: Showing the Correlation between FNAC } \\
\text { Reports and Histo-Pathological Reports (n=57) }\end{array}$} \\
\hline
\end{tabular}

The present study showed the incidence of benign tumours was $82.46 \%$ and malignant tumours were $17.54 \%$. The Pleomorphic adenoma was the commonest tumour (61 \%) of all tumours and constituted $74.46 \%$ of benign tumours. Among malignant parotid tumours mucoepidermoid carcinoma was the commonest tumours. $100 \%$ correlation between FNAC and HPE for mucoepidermoid cancer and adenoid cystic carcinoma was observed. One case of pleomorphic adenoma by FNAC turned out to be adenocarcinoma by HPE and one case of Warthin's tumour by FNAC turn out to be Acinic-cell carcinoma by HPR. Both are rare tumours (Table 12).

\begin{tabular}{|c|c|}
\hline FNAC & HPR \\
\hline Benign tumour (49) & Benign tumour (47) \\
\hline & Malignant tumour (2) \\
\hline Malignant tumour (8) & Malignant tumour (8) \\
\hline Table 12: Showing the Correlation between \\
FNAC and HPE (n=57)
\end{tabular}

The Sensitivity of FNAC for benign tumour was $100 \%$ and for malignant tumour it was $80 \%$. Whereas the specificity of FNAC for benign tumour was $80 \%$ ad for malignant tumour it was $100 \%$ (Table 13).

\begin{tabular}{|c|c|c|}
\hline Tumour & Sensitivity & Specificity \\
\hline Benign & $100 \%$ & $80 \%$ \\
\hline Malignant & $80 \%$ & $100 \%$ \\
\hline \multicolumn{2}{|c|}{ Table 13: Showing the Sensitivity and Specificity } \\
\hline
\end{tabular}

\section{DISCUSSION}

The present study of 57 patients with Parotid gland neoplasm reported in department of General surgery, Govt. medical college, Kozhikode, Kerala between November 2007 and November 2009. Only a few recorded analysis of parotid gland tumours based on significantly large number of cases are published from India. Among them the noted studies are by Narinder Singh et al (255 cases) and Shafkat Ahmed et al (259) cases (Table 14).

\begin{tabular}{|c|c|c|c|}
\hline $\begin{array}{l}\text { Highest } \\
\text { Incidence }\end{array}$ & $\begin{array}{l}\text { Present } \\
\text { Study }\end{array}$ & $\begin{array}{l}\text { Narinder } \\
\text { Singh et AI }\end{array}$ & $\begin{array}{l}\text { Shafkat } \\
\text { Ahmad } \\
\text { Study }\end{array}$ \\
\hline $\begin{array}{l}\text { Benign } \\
\text { tumours }\end{array}$ & $\begin{array}{c}2^{\text {nd }} \text { and 3rd } \\
\text { decade }\end{array}$ & $\begin{array}{l}3^{\text {rd }} \text { and } 4^{\text {th }} \\
\text { decade }\end{array}$ & $\begin{array}{c}3^{\text {rd }} \text { and } 4^{\text {th }} \\
\text { decade }\end{array}$ \\
\hline $\begin{array}{l}\text { Malignant } \\
\text { tumours }\end{array}$ & $\begin{array}{l}3^{\text {rd }} \text { and } 4^{\text {th }} \\
\text { decade }\end{array}$ & $\begin{array}{l}4^{\text {th }} \text { and } 5^{\text {th }} \\
\text { decade }\end{array}$ & $\begin{array}{l}4^{\text {th }} \text { and } 5^{\text {th }} \\
\text { decade }\end{array}$ \\
\hline \multicolumn{4}{|c|}{$\begin{array}{c}\text { Table 14: Showing Comparison of Incidence between } \\
\text { the Present and other Two Studies }\end{array}$} \\
\hline
\end{tabular}

Parotid gland tumours were observed in the age groups of 18 to 70 years. But the highest incidence was in $2^{\text {nd }}$ and $3^{\text {rd }}$ decade for benign tumours and $3^{\text {rd }}$ and $4^{\text {th }}$ decades for malignant tumours. The average age for benign tumours was 39.23 years for malignant tumours it was close to 32.7 years and 44.1 years for malignant tumours as reported by Narinder Singh et al.(8) and 35.7 years for benign and 42.4 for malignant tumours as reported by Shafkath Abrnad study (Table 15).(9)

\begin{tabular}{|c|c|c|c|}
\hline Average & $\begin{array}{c}\text { Present } \\
\text { Study }\end{array}$ & $\begin{array}{c}\text { Narinder } \\
\text { Singh et aI }\end{array}$ & $\begin{array}{c}\text { Shafkat } \\
\text { Ahrnad } \\
\text { Study }\end{array}$ \\
\hline $\begin{array}{c}\text { Benign } \\
\text { tumours }\end{array}$ & 39.23 yrs. & 32.7 yrs. & 35.7 yrs. \\
\hline $\begin{array}{c}\text { Malignant } \\
\text { tumours }\end{array}$ & 44.1 yrs. & 42.4 yrs. & 42.4 yrs. \\
\hline
\end{tabular}

Table 15: Showing the Incidence of Benign and Malignant Tumours between the present Study and other Two Studies

Male to female ratio was 1:1.28. The incidence for benign salivary gland tumours (82.49) is higher than the malignant tumours (17.54\%) comparable to by Shafkath Abrnad study in which benign is $86 \%$ and malignant is $14 \%$. The duration of symptoms ranged from $2 \mathrm{~m}$ days to 8 years. The age range is 18 to 70 yrs. The age range reported by Chan et al (1992) was between 25 and 83 years (Table 16).

\begin{tabular}{|c|c|c|}
\hline & $\begin{array}{c}\text { Present } \\
\text { Study }\end{array}$ & $\begin{array}{l}\text { Shafkat } \\
\text { Ahrnad }\end{array}$ \\
\hline M:F ratio & $1: 1.28$ & 1.1:1 \\
\hline Benign & $82.46 \%$ & $86 \%$ \\
\hline Malignant & 17.54 & $14 \%$ \\
\hline $\begin{array}{l}\text { Duration of } \\
\text { symptoms }\end{array}$ & $2 \mathrm{~m}-8$ yrs. & 45 days - 25 yrs. \\
\hline Age range & $18-70$ yrs. & 46 days -80 yrs. \\
\hline \multicolumn{3}{|c|}{$\begin{array}{l}\text { Table 16: Showing the Comparative Incidence of Parotid } \\
\text { Tumours according to the Age and Duration of } \\
\text { Symptoms }\end{array}$} \\
\hline
\end{tabular}

The commonest symptoms were painless swelling which was present in all cases. Similar observations were made by Loke - Wallance et al and Sharky study.(10) Loke- Wallance et al study reported the range of tumour size in his series to be 1.8-4 cm whereas Sharkey reported a mean size ranging from $0.5-7 \mathrm{~cm} .{ }^{11}$ In the present series, mean tumour size ranged from $1-7 \mathrm{~cm}$ (Table 17).

\begin{tabular}{|c|c|c|c|c|}
\hline & $\begin{array}{c}\text { Present } \\
\text { Study }\end{array}$ & $\begin{array}{c}\text { Shafkat } \\
\text { Ahrnad }\end{array}$ & $\begin{array}{c}\text { Loke } \\
\text { Wallance } \\
\text { et. al }\end{array}$ & Sharkey \\
\hline $\begin{array}{c}\text { Common } \\
\text { Symptom- } \\
\text { Painless } \\
\text { swelling }\end{array}$ & $100 \%$ & $99 \%$ & $100 \%$ & $100 \%$ \\
\hline $\begin{array}{c}\text { Range of } \\
\text { tumour } \\
\text { size }\end{array}$ & $1-7 \mathrm{~cm}$ & $\begin{array}{c}0.5- \\
\mathrm{n}\end{array}$ & $1.8-4 \mathrm{~cm}$ & $0.5-7 \mathrm{~cm}$ \\
\hline $\begin{array}{c}\text { Table 17: Showing the Comparative Study in Relation to } \\
\text { Symptoms and Size of the Tumour }\end{array}$ \\
\hline
\end{tabular}


All the 57 cases were subjected to FNAC, as it was a quick, simple, rapid, inexpensive and harmless procedure. All patients were subjected to surgery. Excised tumour masses were subjected to HPE. The reports by FNAC and HPE were correlated in (Table 12,13). Sensitivity of FNAC for benign tumour was $100 \%$ and for malignant tumour it was $80 \%$ and for malignant tumour was $100 \%$. Thus FNAC was observed as a practical, quick, simple, inexpensive and harmless procedure and a useful technique for the diagnosis of the parotid gland tumours in the present study. There were 2 cases of recurrent parotid gland tumours. Both were pleomorphic adenomas. Both the patients had undergone excision/enucleations for pleomorphic adenoma previously within one to two years. Narinder Singh et al reported recurrence in 10 cases in benign tumours and 8 malignant tumours. Our observations are not consistent with most authors may be because of short follow up period in the present study. In a similar study by Shafkat Ahmed the recurrences were 3 among the malignant tumours and 2 among the benign tumour (Table 18).

\begin{tabular}{|c|c|c|c|}
\hline Recurrence & $\begin{array}{c}\text { Present } \\
\text { Study }\end{array}$ & $\begin{array}{c}\text { Shafkat } \\
\text { Ahmed }\end{array}$ & $\begin{array}{c}\text { Narinder } \\
\text { Singh et Al }\end{array}$ \\
\hline Benign & 2 & 3 & 10 \\
\hline malignant & 0 & 2 & 8 \\
\hline \multicolumn{3}{|c|}{ Table 18: Showing the Comparative Study of Recurrence } \\
of Tumours Parotid Gland \\
\hline
\end{tabular}

Pleomorphic adenoma was the commonest tumour (61\%) of all tumours and constituted $74.46 \%$ of benign tumours. Warthin's tumour was another common benign tumour, about $19.148 \%$ of all benign tumours. Similar high incidence of pleomorphic adenoma $83.9 \%$ was observed by Masanja study of Kenyan population.(11,12) (Table 19).

\begin{tabular}{|c|c|c|}
\hline Benign Tumour & Present Study & Masanja Study \\
\hline $\begin{array}{c}\text { Pleomorphic } \\
\text { adenoma }\end{array}$ & $\begin{array}{c}74.46 \% \text { of } \\
\text { benign tumours }\end{array}$ & $\begin{array}{c}83.9 \% \text { of } \\
\text { benign tumours }\end{array}$ \\
\hline $\begin{array}{c}\text { Table 19: Showing the Comparative Study of Incidence } \\
\text { of Pleomorphic Adenoma of Parotid ( } \mathrm{n}=57 \text { ) }\end{array}$ \\
\hline
\end{tabular}

Warthin's tumour was also found second commonest benign tumour in other series. Among malignant parotid tumours, Mucoepidermoid carcinoma was the commonest tumour in this study. Mucoepidermoid carcinoma was most common malignant tumour amounting to $60 \%$ of malignant tumours and $17.5 \%$ of all parotid tumours. Mucoepidermoid carcinoma was found in about $14 \%$ of parotid tumours by Hill and about $35 \%$ of malignant tumours by Speight and common malignant tumour in other studies.(13,14) Adenoid cystic carcinoma was another frequently found malignant tumour in the present study. Incidence of Acinic cell carcinoma and was identical to other published series.

\begin{tabular}{|c|c|c|c|}
\hline $\begin{array}{c}\text { Malignant } \\
\text { Tumour }\end{array}$ & $\begin{array}{c}\text { Present } \\
\text { Study }\end{array}$ & $\begin{array}{c}\text { Hill } \\
\text { Study }\end{array}$ & $\begin{array}{c}\text { Speight } \\
\text { Study }\end{array}$ \\
\hline $\begin{array}{c}\text { Mucoepidermoid } \\
\text { tumour }\end{array}$ & $\begin{array}{c}60 \% \text { of } \\
\text { malignant } \\
\text { tumours }\end{array}$ & $\begin{array}{c}14 \% \text { of } \\
\text { malignant } \\
\text { tumours }\end{array}$ & $\begin{array}{c}35 \% \\
\text { malignant } \\
\text { tumours }\end{array}$ \\
\hline \multicolumn{3}{|c|}{ Table 20: Showing the Incidence of Muco-Epidermoid } \\
Tumours (Table 20)
\end{tabular}

In the Cleveland clinic foundation study, $46.1 \%$ patients had post-operative transient facial nerve palsy and 3.6\% patient had permanent facial nerve palsy.
In our study 3 patients presented with preoperative facial nerve palsy among them two with permanent and one with temporary facial nerve palsy. In the remaining 54 patients, 13 had immediate post-operative temporary facial nerve palsy. No one had permanent post op facial nerve palsy. So $24.07 \%$ patients had immediate post op temporary facial weakness as new complication (Table 21).

\section{Facial Nerve Weakness}

\begin{tabular}{|c|c|c|}
\hline $\begin{array}{c}\text { Facial Nerve } \\
\text { Weakness }\end{array}$ & $\begin{array}{c}\text { Present } \\
\text { Study }\end{array}$ & $\begin{array}{c}\text { The Cleveland } \\
\text { Clinic Foundation } \\
\text { Study }\end{array}$ \\
\hline $\begin{array}{c}\text { Immediate post } \\
\text { op transient } \\
\text { facial nerve palsy }\end{array}$ & $24.07 \%$ & $46.1 \%$ \\
\hline $\begin{array}{c}\text { Permanent post } \\
\text { op facial nerve } \\
\text { palsy }\end{array}$ & $0 \%$ & $3.6 \%$ \\
\hline \multicolumn{2}{|c|}{$\begin{array}{c}\text { Table 21: Showing the Comparative Study } \\
\text { of Incidence of Facial Weakness }\end{array}$} \\
\hline
\end{tabular}

\section{CONCLUSIONS}

Parotid Tumours were observed in the age groups of 18-76 years. Male to female ratio was $1: 1.28$. The highest incidence was in the $2^{\text {nd }}$ and $3^{\text {rd }}$ decades in benign and $3^{\text {rd }}$ and $4^{\text {th }}$ decades for malignant tumours. $100 \%$ patients presented with a swelling or palpable mass. The benign tumours constitute $82.46 \%$ and malignant tumours $17.54 \%$. Pleomorphic adenoma was the commonest tumour $(61 \%)$ of all tumours and constitutes $74.46 \%$ of benign tumours. Among malignant parotid tumours mucoepidermoid carcinoma was the commonest tumour. Sensitivity of FNAC for benign tumour was $100 \%$ and for malignant tumour was $80 \%$.

Specificity of FNAC for benign tumour was $80 \%$ and for malignant tumour was $100 \%$. There were no complications attributed to FNAC. FNAC is very useful in the diagnosis of salivary gland swelling. There were total 2 recurrent cases and both were pleomorphic adenoma. The treatment modalities used were superficial parotidectomy, superficial parotidectomy with excision of deep lobe tumours, total conservative parotidectomy, total radical parotidectomy, excision and enucleations. $24.07 \%$ patients had immediate temporary post op facial weakness and no one had permanent post op facial nerve palsy. 3.5\% patient had post op flap necrosis and wound infection.

\section{REFERENCES}

1. Ayoub OM, Bhatia K, Mal RK. Pleomorphic adenoma of the parotid gland: is long-term follow-up needed? Auris Nasus Larynx 2002;29(3):283-5.

2. Frommer J. The human accessory parotid gland: its incidence, nature, and significance. Oral Surg Oral Med Oral Pathol 1977;43(5):671-6.

3. Eugene N Myers, Robert L Ferris (Eds.) Salivary gland disorders 2002; $6^{\text {th }}$ ed:239-51.

4. Auclair PL, Ellis GL. Atypical features in salivary gland mixed tumours: their relationship to malignant transformation. Mod Pathol 1996;9(6):652-7.

5. Buxton RW, Maxwell JH, French AJ. Surgical treatment of epithelial tumours of the parotid gland. Surg Gynecol Obstet 1953;97(4):401-16. 
6. Eveson JW, Cawson RA. Salivary gland tumours a review of 2410 cases with particular reference to histological types, site, age and sex distribution. J Pathol 1985;146(1):51-8.

7. Eveson JW, Cawson RA. Tumours of the minor (oropharyngeal) salivary glands: a demographic study of 336 cases. J Oral Pathol 1985;14(6):500-9.

8. Narinder Singh KS, Mehdratta, Satyanand. Study of salivary gland tumours. Indian journal of Surgery 1968;193-206.

9. Shafkat Abrnad, Mohainmad Lateef, Rouf Ahmad. Clinicopathological study of primary salivary-gland tumours in Kashmir. Indian journal of surgery 2001;34(2):236-43.

10. Chan May KM, McGuire LJ, King W, et al. Joseph cytodiagnosis of 112 salivary gland tumours. Acta Cytologica 1992;36:353-63.
11. Seifert G, Sobin LH. The world health organization's histological classification of salivary gland tumours a commentary on the second edition. Cancer 1992;70(2):379-85.

12. Pinkston JA, Cole P. Incidence rates of salivary gland tumours: results from a population-based study. Otolaryngol Head Neck Surg 1999;120(6):834-40.

13. Solange Souza Lima, Andréa Ferreira Soares, Rivadávio Fernandes Batista de Amorim, et al. Epidemiologic profile of salivary gland neoplasms: analysis of 245 cases. Bras J Otorrinolaringol 2005;71(3):335-40.

14. Hill AG. Major salivary gland tumours in a rural kenyan hospital. East Afir Med J 2005;79:8-10. 